\title{
Effect of Green Synthesized Zinc Oxide Nanoparticles on the Physiological Parameters and Gum Production of the Saravan Landrace of Guar (Cyamopsis tetragonoloba L.)
}

\author{
Safoora Bazzi ${ }^{12^{*}}$, Jafar Valizadeh ${ }^{3}$, Moharam Valizadeh ${ }^{4}$, Ali Movafeghi ${ }^{{ }^{*}}$ \\ ${ }^{1}$ Department of Plant Sciences, Faculty of Natural Sciences, University of Tabriz, Tabriz, Iran \\ ${ }^{2}$ Department of Biology, Faculty of Sciences, Payame Noor University \\ ${ }^{3}$ Department of Biology, Faculty of Sciences, University of Sistan and Baluchestan, Zahedan, Iran \\ ${ }^{4}$ Research Center of Medicinal and Ornamental Plants, University of Sistan and Baluchestan, Zahedan, Iran
}

\section{*Correspondence to} Safoora Bazzi, Email: safoura_bazzi@tabrizu.ac.ir; Ali Movafeghi, Email: movafeghi@ tabrizu.ac.ir

Received July 11,2021 Accepted August 25, 2021 Published online September 30,2021

\begin{abstract}
Introduction: The plant species Cyamopsis tetragonoloba L. (Fabaceae) is a source of guar gum that has a variety of applications in the pharmaceutical industry because of its therapeutic properties. Other parts of the plant are also used as food and fodder. This study was conducted to evaluate some physiological changes and gum production of guar in response to foliar spraying with synthesized zinc oxide nanoparticles (ZnO-NPs).

Methods: ZnO-NPs were synthesized using guar gum by the co-precipitation method. The properties of the ZnO-NPs were investigated using various analytical techniques, including ultraviolet-visible spectroscopy (UV-Vis), scanning electron microscopy (SEM), transmission electron microscope (TEM), energy dispersive X-ray (EDX), Fourier transform infrared spectroscopy (FTIR), and X-ray diffraction (XRD). The nanoparticles were sprayed on the leaves of the Saravan landrace of guar to study their effects on the physiological properties of the plant. The experiments were performed in a completely randomized design with three replications. Results: Treatment of plants with $\mathrm{ZnO}-\mathrm{NPs}$ resulted in an improvement of some physiological properties. After exposure to $500 \mathrm{mg} / \mathrm{L}$ of $\mathrm{ZnO}-\mathrm{NPs}$, the contents of chlorophyll a, chlorophyll b, total chlorophyll, carotenoids, gum, and soluble protein were increased by $47.88 \%, 78.43 \%$, $54.37 \mathrm{~T}, 29.41 \%, 55.08 \%$, and $52.12 \%$, respectively. Additionally, the amount of $\mathrm{Zn}$ and insoluble sugars showed the highest increase, by 3.96 and 4.31 times, respectively. In contrast, soluble sugars content as well as the activity of catalase (CAT), peroxidase (POX), and ascorbate peroxidase (APX) reduced 0.69-, 2.23-, 1.60-, and 3.91-fold, respectively.

Conclusion: $\mathrm{ZnO}-\mathrm{NPs}$ improved the physiological properties of guar at different concentrations, with the best effects obtained at the maximum concentration of $500 \mathrm{mg} / \mathrm{L}$. The results of this study suggest that the ZnO-NPs synthesized by the biocompatible process are appropriate candidates to prepare guar gum to be used in pharmaceutical and therapeutic-based approaches.

Keywords: Ascorbate peroxidase, Chlorophyll, Cyamopsis tetragonoloba, Guar gum, Nanoparticles, Zinc oxide
\end{abstract}

in the control of bowel movements, colon cancer, hypolipidemic, hypoglycemic, and heart disease., ${ }^{2,3}$ Guar gum has been reported to be helpful in the treatment of SARS-COV-2 infections. ${ }^{4}$ Various parts of guar plant, including the seeds and green pods, are used as food and fodder. ${ }^{5}$

Gums in general are mainly polysaccharides found in various parts of different plant species and are potent candidates for green synthesis and stabilization of nanoparticles such as

(C) 2021 The Author(s); Published by Zabol University of Medical Sciences. This is an open-access article distributed under the terms of the Creative Commons Attribution License (http://creativecommons.org/licenses/by/4.0), which permits unrestricted use, distribution, and reproduction in any medium, provided the original work is properly cited. 
zinc oxide nanoparticles (ZnO-NPs). ${ }^{6}$ Although $\mathrm{ZnO}$ NPs can be synthesized by many different techniques; biological methods are relatively fast, inexpensive, and environmentally friendly. ${ }^{7}$ Plant materials containing reducing agents such as polysaccharides, phenolics, flavonoids, and terpenoids are more suitable for the synthesis of nanoparticles. ${ }^{8}$

Zinc $(\mathrm{Zn})$ is an essential element for many structural and functional proteins in living cells. ${ }^{9}$ It plays a vital role not only as a cofactor for many enzymes, but also in the protection and resistance of the structural integrity of cell membrane. ${ }^{10}$ The effect of $\mathrm{Zn}$ on plants depends on the application form, i.e., ionic, bulk, or nanoscale; the nanoscale form is used in this study. ${ }^{11}$ Half of the world's agricultural soils are severely zinc deficient, and zinc deficiency poses a risk to human health. Nearly one-third of the world's population consumes $\mathrm{Zn}$ improperly. To solve this problem, adding zinc to agricultural products can help protect human health. ZnO-NPs can be applied either to the soil or directly to the leaf surface. ${ }^{12}$ The foliar spray used here is a successful and efficient low-cost nutrition method that increases yield even in deficient soils. ${ }^{13}$ Direct application of $\mathrm{ZnO}-\mathrm{NPs}$ to the soil may reduce the mobility of nanoparticles by binding to soil colloids. ${ }^{14}$ In the present work, green synthesis of $\mathrm{ZnO}$ NPs was carried out using guar gum to study its effect at different concentrations on physiological parameters of a landrace of guar from Saravan.

\section{Material and Methods \\ Preparation of Guar Gum}

Seeds of a local guar landrace, namely Saravan, were provided by the Agricultural Research Center, Iranshahr, Sistan and Baluchestan province, Iran. The taxonomic validation of this landrace was previously performed. ${ }^{15}$ Seeds were treated with warm water and rubbed manually to separate endosperm from the husk. The endosperm was air-dried and pulverized in a grinder to obtain a paleyellow powder.

\section{Synthesis of ZnO-NPs by Co-precipitation Procedure}

The green synthesis of $\mathrm{ZnO}-\mathrm{NPs}$ was carried out by the co-precipitation method with a few modifications to the procedure. ${ }^{16} 0.3 \mathrm{~g}$ guar gum was added to $40 \mathrm{~mL}$ of deionized water and mixed for 90 minutes at $60^{\circ} \mathrm{C}$. Meanwhile, $4.5 \mathrm{~g}$ of $\mathrm{Zn}\left(\mathrm{NO}_{3}\right)_{2} \cdot 4 \mathrm{H}_{2} \mathrm{O}$ was added to $15 \mathrm{~mL}$ of deionized water and stirred for 10 minutes. The zinc nitrate solvent was mixed with the guar gum solution for 2 hours at $80^{\circ} \mathrm{C}$. Then, $10 \mathrm{~mL} \mathrm{NaOH}(2 \mathrm{M})$ was added drop-wise to the mixture until $\mathrm{pH} 12$ was reached, a reflux tube was used to avoid evaporation. After 8 hours, the attained white solution was centrifuged for 15 minutes at $3000 \mathrm{rpm}$. The supernatant was discarded and the precipitate was eluted three times with $96 \%$ ethanol. It was transferred to the oven at $100^{\circ} \mathrm{C}$ for 12 hours before it was calcined at $600^{\circ} \mathrm{C}$ for 1 hour to form $\mathrm{ZnO}-\mathrm{NPs}$.

\section{Characterization of $\mathrm{ZnO}-\mathrm{NPs}$}

After dispersing the synthesized $\mathrm{ZnO}-\mathrm{NPs}$ in ethanol using a sonicator, their absorbance was measured at $300-600 \mathrm{~nm}$ by an ultraviolet-visible (UV-Vis) spectrophotometer (NACH DR 5000). The morphology, and size of nanoparticles was examined after gold coating procedure with a field emission scanning electron microscope (FE-SEM, TESCAN MIRA3 XMU) at a voltage of $15 \mathrm{kV}$. In addition, the size and shape of the nanoparticles were further analyzed using a transmission electron microscope (TEM, Zeiss-EM10C-100kV). Energy dispersive X-ray system (EDX) attached to SEM was used for chemical study of ZnO-NPs. Fourier transform infrared spectroscopy (FTIR, Bruker Tensor II) was recorded in the area of $400-4000 \mathrm{~cm}^{-1}$. X-Ray diffraction (XRD, D8 Advance Bruker AXS) was performed at a voltage of $40 \mathrm{kV}$, a current of $30 \mathrm{~mA}$ with $\mathrm{Cu}$-Ka radiation $(\lambda=0.15406 \mathrm{~nm})$.

\section{Culture of Plants}

The seeds were sown in a clay loamy soil containing $30 \%$ vermicompost in the green-house of Sistan and Baluchestan University, Zahedan, Iran. During the treatment period, the greenhouse temperature was between $25 \pm 2{ }^{\circ} \mathrm{C}$ and the humidity was 30 -35\%. Drip irrigation was done twice a week.

\section{Exposure to $\mathrm{ZnO}-\mathrm{NPs}$}

Different concentrations $(0,25,50,100,200$, and 500 $\mathrm{mg} / \mathrm{L}$ ) of the synthesized $\mathrm{ZnO}-\mathrm{NPs}$ were provided. In order to prevent NP aggregation, the suspensions were sonicated for 45 minutes. Foliar spray was performed twice, 20 and 27 days after planting. Experiments were performed in a completely randomized experimental design with three replicates.

\section{Assessing the Concentration of $\mathrm{Zn}$}

The harvest was carried out 34 days after sowing at the vegetative stage to evaluate physiological traits. Zinc content in leaf tissues was measured using a method previously reported by Niesiobedzka. ${ }^{17} 0.5 \mathrm{~g}$ dried leaves of guar digested with $5 \mathrm{~mL}$ mixture of perchloric acid and nitric acid 1:3 on a heater. Fully digested samples were suspended in $2.5 \mathrm{~mL}$ of $10 \%$ hydrochloric acid in a final volume of $10 \mathrm{~mL}$ and assayed by means of an atomic absorption spectrophotometer (Analytik Jena - novAA 400 P).

\section{Photosynthetic Pigments Assay}

Measurements of chlorophyll a, chlorophyll b, total chlorophyll and carotenoids in leaves performed using the method explained in Ref. ${ }^{18} 0.01 \mathrm{~g}$ of fresh leaves was homogenized in a mortar containing $10 \mathrm{~mL}$ of ethanol 
95\%. The absorption of the solutions was then measured by a JENWAY 6305 spectrophotometer to evaluate the quantity of chlorophyll a, chlorophyll b, and carotenoids at wavelengths of 645,663 and 470 , respectively. The amounts of the pigments were computed using the following formulas:

$C_{\mathrm{a}}=13.36 A_{663}-5.19 A_{645}, \quad C_{\mathrm{b}}=27.43 A_{645}-8.12 A_{663}$, $C_{\mathrm{a}+\mathrm{b}}=5.24 A_{663}+22.24 A_{645}, \quad C_{\mathrm{x}+\mathrm{c}}=1000 A_{470}-2.13 C_{\mathrm{a}}-$ $97.64 C_{\mathrm{b}} / 209$

where $(\mathrm{Ca}),(\mathrm{Cb}),(\mathrm{Ca}+\mathrm{b})$, and $(\mathrm{Cx}+\mathrm{c})$, represent chlorophyll a, chlorophyll b, total chlorophyll, and total carotenoid, respectively and " $A$ " represents the absorbance of the samples.

\section{Measurement of Soluble and Insoluble Sugars}

Measurement of the sugars was accomplished on the basis of the phenol-sulfuric acid method. ${ }^{19} 5 \mathrm{~mL}$ of ethanol $70 \%$ was added to $50 \mathrm{mg}$ of dry material and incubated at $4^{\circ} \mathrm{C}$ for one week. The extracts were centrifuged at $5000 \mathrm{~g}$ for 30 minutes. Supernatants were utilized to measure soluble sugars and residual sediments to quantify insoluble sugars. $500 \mu \mathrm{L}$ of supernatant was mixed with $1 \mathrm{~mL}$ of phenol $5 \%$ and $5 \mathrm{~mL}$ of $\mathrm{H}_{2} \mathrm{SO}_{4} 96 \%$, stirred rapidly and was shaken after 30 minutes. The sediment was boiled in $10 \mathrm{~mL}$ distilled water for 15 minutes, filtered, and mixed with phenol and $\mathrm{H}_{2} \mathrm{SO}_{4}$. The absorption of each solution was measured at $485 \mathrm{~nm}$. The sugar content was expressed using a glucose standard curve and reported in mg per gram dry weight.

\section{Estimation of Polysaccharides in Gum}

$0.1 \mathrm{~g}$ of guar gum was shaken in $5 \mathrm{~mL}$ ethanol and heated for 15 minutes to remove monosaccharides and oligosaccharides. ${ }^{20}$ This process was repeated after centrifugation and removal of supernatant. The acquired precipitate was mixed with $10 \mathrm{~mL}$ of acidified distilled water with $\mathrm{HCl}(\mathrm{pH}=3.5)$ and heated at $96^{\circ} \mathrm{C}$ for 10 minutes. The phenol-sulfuric acid method was applied to assess the amount of gum polysaccharide content in the solution. ${ }^{19}$

\section{Protein Content and Antioxidant Enzyme Assay}

$0.1 \mathrm{~g}$ of samples was homogenized in ice-cold phosphatebuffered solution $(50 \mathrm{mM}, \mathrm{pH}=7)$. The mixture was centrifuged at $5000 \mathrm{~g}$ for 20 minutes at $4^{\circ} \mathrm{C}$. The protein concentration in the supernatant (leaf extract) was determined using bovine serum albumin as a standard according to Bradford's study. ${ }^{21}$

Catalase (CAT) activity was determined based on the protocol suggested in Chance and Maehly's study. ${ }^{22}$

TheCATactivity was calculated using the decomposition of $\mathrm{H}_{2} \mathrm{O}_{2}$ by reducing the absorption at $240 \mathrm{~nm}$ (extinction coefficient, $\left.\varepsilon=40 \mathrm{mM}^{-1} \mathrm{~cm}^{-1}\right)$. The sampling mixture $(1.5$ $\mathrm{mL}$ ) included $975 \mu \mathrm{L}$ of $50 \mathrm{mM}$ phosphate buffer $(\mathrm{pH}$ 7.0), $500 \mu \mathrm{L}$ of leaf extract and $500 \mu \mathrm{L}$ of $200 \mathrm{mM} \mathrm{H}_{2} \mathrm{O}_{2}$.
CAT activity was expressed as $\mu \mathrm{mol} \mathrm{H}_{2} \mathrm{O}_{2}$ decomposed $\mathrm{min}^{-1}$ per $\mathrm{mg}$ of protein. Peroxidase (POD) activity was assayed using the oxidation of guaiacol and increasing the absorption at $470 \mathrm{~nm}$ (extinction coefficient, $\varepsilon=25.5$ $\left.\mathrm{mM}^{-1} \mathrm{~cm}^{-1}\right)$. The extraction mixture $(1 \mathrm{~mL})$ contained $350 \mu \mathrm{L}$ of $10 \mathrm{mM}$ phosphate buffer ( $\mathrm{pH} 7.0$ ), $300 \mu \mathrm{L}$ of guaiacol $(4 \mathrm{mM}), 50 \mu \mathrm{L}$ of leaf extract and $300 \mu \mathrm{L}$ of 5 $\mathrm{mM} \mathrm{H}_{2} \mathrm{O}_{2}$ for $1 \mathrm{~min}^{22}$. POD activity was expressed as the enzyme quantity required for the oxidation of $1 \mu \mathrm{M}$ of guaiacol to tetragaiacol $\mathrm{min}^{-1} \mathrm{mg}^{-1}$ protein.

To evaluate ascorbate peroxidase (APX), the oxidation of ascorbic acid was assessed by decreasing the absorbance at $290 \mathrm{~nm}$ (extinction coefficient, $\varepsilon=2.8 \mathrm{mM}^{-1} \mathrm{~cm}^{-1}$ ) based on the protocol suggested in Ref. ${ }^{23}$ The sampling mixture $(1 \mathrm{~mL})$ consisted of $300 \mu \mathrm{L}$ of $50 \mathrm{mM}$ phosphate buffer (pH 7.0), $200 \mu \mathrm{L}$ of $2 \mathrm{mM}$ EDTA, $200 \mu \mathrm{L}$ of $5 \mathrm{mM}$ ascorbic acid, $200 \mu \mathrm{L}$ of $50 \mathrm{mM}$ bovine serum albumin, 50 $\mu \mathrm{L}$ of leaf extract, and $50 \mu \mathrm{L}$ of $1 \mathrm{mM} \mathrm{H}_{2} \mathrm{O}_{2}$. APX enzymespecific activity was stated as $\mu \mathrm{mol}$ ascorbic acid oxidized $\mathrm{min}^{-1} \mathrm{mg}^{-1}$ protein.

\section{Statistical Analysis}

All data were submitted to statistical analysis using SPSS software and the results were presented as the mean of three replicates \pm SE (standard error). The significance of differences between treatments was evaluated by one-way ANOVA $(P<0.05)$ followed by Duncan's multiple range test.

\section{Results \\ Characteristics of $\mathrm{ZnO}$-NPs}

$U V$-Vis Spectrum

The UV-Vis absorption spectrum of the green synthesized $\mathrm{ZnO}-\mathrm{NPs}$ in water is shown in Figure 1. The maximum absorption appeared at $375 \mathrm{~nm}$, which can be ascribed to the intrinsic band-gap absorption of $\mathrm{ZnO}$ owing to the electron transfer from the valence to the conduction band. ${ }^{24}$

\section{Morphologic Properties of ZnO-NPs and EDX Analysis} A hexagonal morphology for the synthesized $\mathrm{ZnO}-\mathrm{NPs}$ (Figure 2A) was observed in FE-SEM and confirmed by TEM analysis (Figure 2b). According to the histogram of particle size distribution of $\mathrm{ZnO}$ obtained from FE-SEM data, the average diameter of nanoparticles was $\sim 40 \mathrm{~nm}$ (Figure 2C). EDX spectra of $\mathrm{ZnO}-\mathrm{NPs}$ revealed correct elemental composition and stoichiometry (Figure 2D). The obtained peaks clearly indicated presence of oxygen and $\mathrm{Zn}$ elements.

\section{FTIR analysis}

FTIR spectrum showed the peak of $\mathrm{Zn}-\mathrm{O}$ around 409-544 $\mathrm{cm}^{-1}$ (Figure 3). The peak for $\mathrm{OH}$ stretching was observed at $3373.35 \mathrm{~cm}^{-1} .^{25}$ 


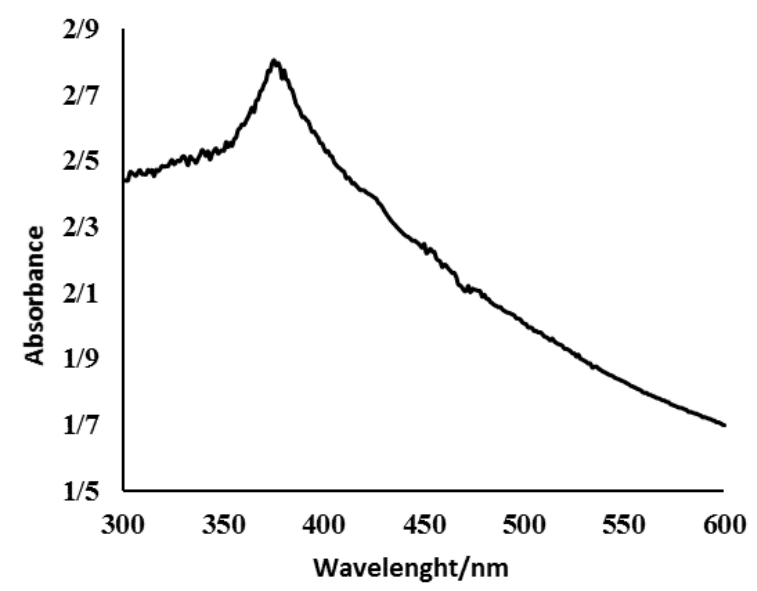

Figure 1. UV-Visible Spectrum of Synthesized ZnO-NPs.

\section{XRD Analysis}

$\mathrm{XRD}$ analysis of the $\mathrm{ZnO}$-NPs revealed an average size of $40 \mathrm{~nm}$. For the nanoparticles, estimated according to Scherrer's formula. $(D=k \lambda / \beta \cos \theta)$ (Figure 4$)$, where $D$ is the average size of $\mathrm{ZnO}-\mathrm{NPs}, \mathrm{K}$ is the Scherrer constant around $0.9, \lambda$ is the $X$ - rays's wavelength of $1.54 \AA, \beta$ is the peak width at half maximum (FWHM), and $\theta$ is the Bragg diffraction angle. The diffraction peaks at $2 \theta$ of $31.77^{\circ}, 34.40^{\circ}, 36.26^{\circ}, 47.48^{\circ}, 56.59^{\circ}, 62.85^{\circ}, 66.37^{\circ}$, $67.93^{\circ}, 69.04^{\circ}, 72.53^{\circ}$ and $76.87^{\circ}$, were referred to $(100)$, (002), (101), (102), (110), (103), (200), (112), (201), (004) and (202), respectively. The diffraction peaks of the pattern correspond to the characteristic hexagonal phase (wurtzite structure) of $\mathrm{ZnO}-\mathrm{NPs}$. The sharp diffraction peaks show that the $\mathrm{ZnO}-\mathrm{NPs}$ have a crystalline structure. ${ }^{26}$

\section{Effect of ZnO-NPs on Guar Plant}

Effect of ZnO-NPs on Zn Concentration in the Leaf According to the data of Table 1, an increase in the concentration of $\mathrm{ZnO}-\mathrm{NPs}$ is accompanied by an increase in the $\mathrm{Zn}$ content in guar leaves. The highest $\mathrm{Zn}$ concentration was observed in the plants treated with $500 \mathrm{mg} \mathrm{L}^{-1} \mathrm{ZnO}-\mathrm{NPs}\left(114.16 \mu \mathrm{g} \mathrm{g}^{-1} \mathrm{FW}\right)$, and the lowest amount was in the control group $\left(28.81 \mu^{g^{-1}} \mathrm{FW}\right)$.

Influence of ZnO-NPs on Chlorophyll and Carotenoid Content

Increasing the concentration of $\mathrm{ZnO}-\mathrm{NPs}$ increased the level of chlorophyll a, chlorophyll b, Total Chlorophyll,
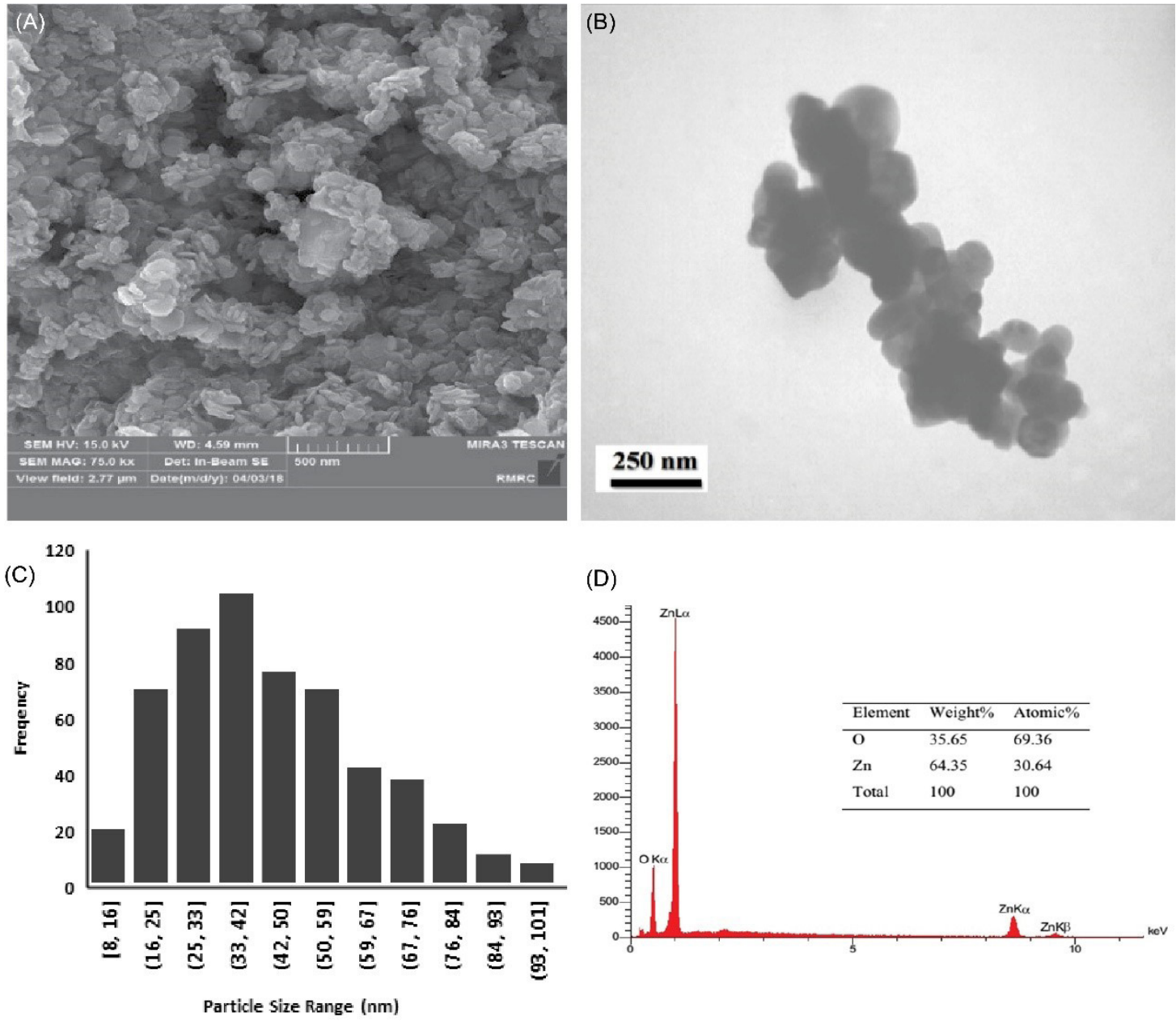

Figure 2. (a) FE-SEM micrographic image of the synthesized ZnO-NPs, (b) TEM micrographic image of ZnO-NPs, (c) Particle size distribution of ZnO-NPs (d) EDX spectroscopy of the ZnO-NPs, inset: atomic composition of the elements in percent. 


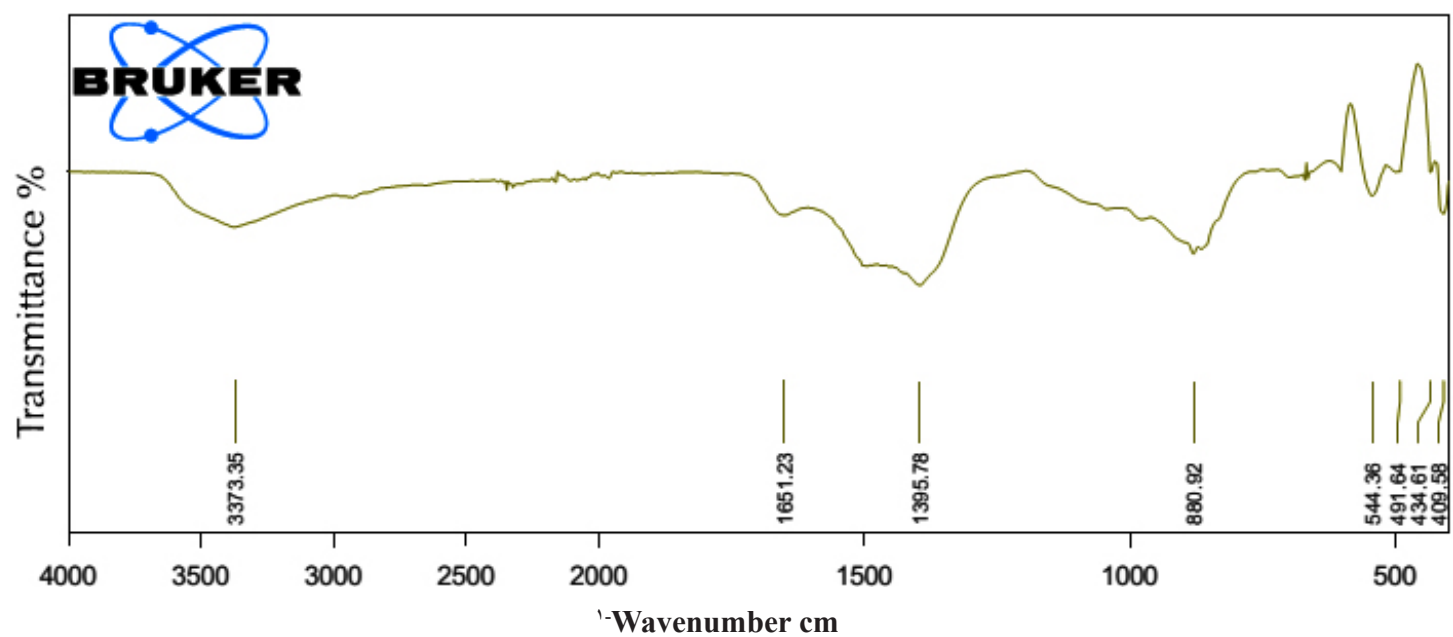

Figure 3. FTIR spectrum of ZnO-NPs.

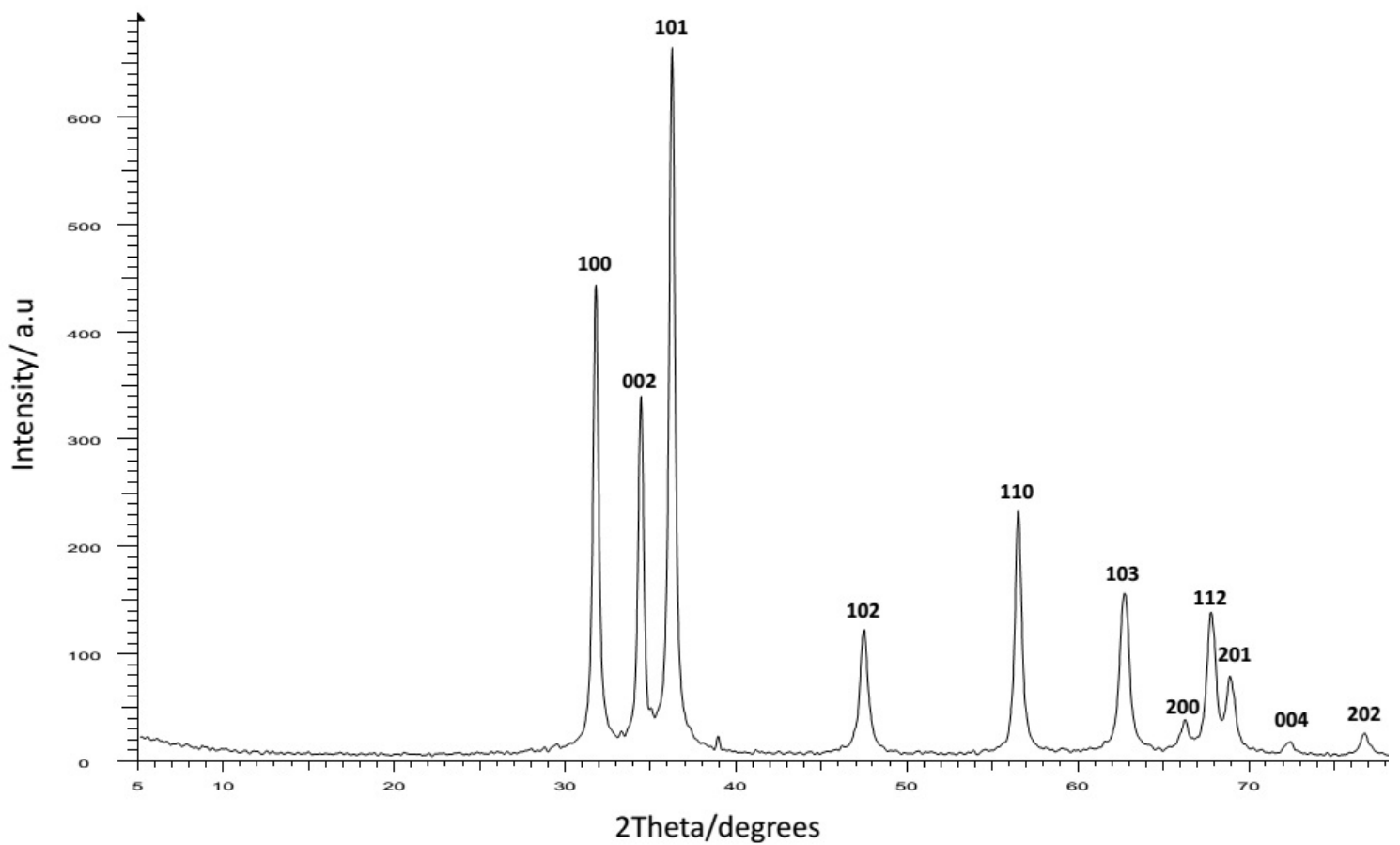

Figure 4. XRD spectrum of $\mathrm{ZnO}-\mathrm{NPs}$.

and carotenoids by $47.88 \%, 78.43 \%, 54.37 \%$, and $29.41 \%$, respectively, in leaves of guar compared to control. The highest pigment values were obtained with $500 \mathrm{mg} \mathrm{L}^{-1}$ ZnO-NPs (Table 1).

\section{Sugar Content}

The results obtained for soluble and insoluble sugars are shown in Table 2. The data showed that the soluble sugar content slightly decreased with increasing concentration of $\mathrm{ZnO}$-NPs and reached its lowest value at the highest concentration of $\mathrm{ZnO}-\mathrm{NPs}\left(500 \mathrm{mg} \mathrm{L}^{-1}\right.$ ) after a decrease of $30.57 \%$. In contrast, the increase in the concentration of the nanoparticles was accompanied by an increase by 4.31 folds in insoluble sugar content at the maximum concentration of $\mathrm{ZnO}-\mathrm{NPs}$.

\section{Gum}

According to Table 2, the production of gum was improved by increasing the concentration of nanoparticles. The highest amount of gum was obtained at a concentration of $500 \mathrm{mg} \mathrm{L}^{-1}$ of $\mathrm{ZnO}-\mathrm{NPs}, 1.55$ times higher than the control sample.

\section{Protein Content}

The content of soluble proteins increased after treatment with $\mathrm{ZnO}$-NPs (Table 2). The maximum concentration of $\mathrm{ZnO}$-NPs (500 $\mathrm{mg} \mathrm{L}^{-1}$ ) increased the soluble protein content by $52.12 \%$ compared to the control.

Antioxidant Enzymes (CAT, POX, APX)

The activity of the studied antioxidant enzymes 
Table 1. Effect of ZnO-NPs Treatments on Zn Concentration and Photosynthetic Pigments of Saravan landrace of Guar

\begin{tabular}{|c|c|c|c|c|c|}
\hline $\begin{array}{l}\text { Concentration of } \mathrm{ZnO} \\
\mathrm{NPs}\left(\mathrm{mg} \mathrm{L}^{-1}\right)\end{array}$ & $\begin{array}{l}\text { Zn Concentration in } \\
\text { Leaves }\left(\mu \mathrm{g} \mathrm{g}^{-1} \mathrm{FW}\right)\end{array}$ & $\begin{array}{l}\text { Chlorophyll a } \\
\left(\mathrm{mg} \mathrm{g}^{-1} \mathrm{FW}\right)\end{array}$ & $\begin{array}{l}\text { Chlorophyll b } \\
\left(\mathrm{mg} \mathrm{g}^{-1} \mathrm{FW}\right)\end{array}$ & $\begin{array}{l}\text { Total Chlorophyll (mg } \\
\left.\mathrm{g}^{-1} \mathrm{FW}\right)\end{array}$ & $\begin{array}{r}\text { Carotenoids } \\
\left(\mathrm{mg} \mathrm{g}^{-1} \mathrm{FW}\right)\end{array}$ \\
\hline 0 & $28.81 \pm 1.70 \mathrm{~d}$ & $2.13 \pm 0.05 \mathrm{C}$ & $0.51 \pm 0.05 \mathrm{c}$ & $2.63 \pm 0.10 \mathrm{c}$ & $0.68 \pm 0.04 \mathrm{~cd}$ \\
\hline 25 & $33.26 \pm 7.53 \mathrm{~d}$ & $2.20 \pm 0.17 b c$ & $0.49 \pm 0.04 \mathrm{c}$ & $2.69 \pm 0.20 \mathrm{C}$ & $0.64 \pm 0.03 \mathrm{~d}$ \\
\hline 50 & $57.28 \pm 2.35 \mathrm{C}$ & $2.34 \pm 0.14 \mathrm{bc}$ & $0.56 \pm 0.02 \mathrm{c}$ & $2.89 \pm 0.16 \mathrm{bc}$ & $0.73 \pm 0.02 \mathrm{c}$ \\
\hline 100 & $68.02 \pm 5.85 \mathrm{c}$ & $2.47 \pm 0.20 b c$ & $0.68 \pm 0.02 \mathrm{~b}$ & $3.15 \pm 0.22 \mathrm{bc}$ & $0.73 \pm 0.02 \mathrm{c}$ \\
\hline 200 & $84.99 \pm 0.63 b$ & $2.67 \pm 0.16 b$ & $0.72 \pm 0.06 \mathrm{~b}$ & $3.39 \pm 0.22 \mathrm{a}$ & $0.80 \pm 0.01 b$ \\
\hline 500 & $114.16 \pm 0.41 \mathrm{a}$ & $3.15 \pm 0.09 \mathrm{a}$ & $0.91 \pm 0.04 \mathrm{a}$ & $4.06 \pm 0.11 \mathrm{a}$ & $0.88 \pm 0.02 \mathrm{a}$ \\
\hline
\end{tabular}

Data represent means \pm SE of replications. Similar lower letters indicate that there is no significant difference at $P<0.05$.

Table 2. Effect of ZnO-NPs Treatments on Soluble Sugars, Insoluble Sugars, Gum, Soluble Protein, and Antioxidant Enzymes on Saravan landrace of Guar

\begin{tabular}{|c|c|c|c|c|c|c|c|}
\hline $\begin{array}{l}\text { Concentration } \\
\text { of ZnO-NPs (mg L-1) }\end{array}$ & $\begin{array}{l}\text { Soluble Sugar (mg } \\
\text { g-1 DW) }\end{array}$ & $\begin{array}{l}\text { Insoluble Sugar } \\
(\mathrm{mg} \mathrm{g}-1 \mathrm{DW})\end{array}$ & $\begin{array}{l}\text { Gum } \\
(\mathrm{mg} \mathrm{g}-1 \mathrm{DW})\end{array}$ & $\begin{array}{l}\text { Soluble Protein } \\
\text { (mg g-1 FW) }\end{array}$ & $\begin{array}{l}\text { CAT } \\
\text { (Umg-1 Protein) }\end{array}$ & $\begin{array}{l}\text { POX } \\
\text { (Umg-1 Protein) }\end{array}$ & $\begin{array}{l}\text { APX } \\
\text { (Umg-1 Protein) }\end{array}$ \\
\hline 0 & $1.57 \pm 0.29 \mathrm{a}$ & $0.132 \pm 0.008 f$ & $4.23 \pm 0.08 \mathrm{c}$ & $1.88 \pm 0.14 b$ & $1.03 \pm 0.03 \mathrm{a}$ & $7.37 \pm 0.20 \mathrm{a}$ & $7.17 \pm 0.55 \mathrm{a}$ \\
\hline 25 & $1.44 \pm 0.02 \mathrm{ab}$ & $0.230 \pm 0.024 \mathrm{e}$ & $4.35 \pm 0.17 c$ & $2.28 \pm 0.23 \mathrm{ab}$ & $0.75 \pm 0.02 b$ & $7.11 \pm 0.87 \mathrm{a}$ & $6.19 \pm 0.18 \mathrm{ab}$ \\
\hline 50 & $1.29 \pm 0.01 \mathrm{ab}$ & $0.329 \pm 0.007 d$ & $5.04 \pm 0.29 b$ & $2.63 \pm 0.07 \mathrm{a}$ & $0.74 \pm 0.02 \mathrm{~b}$ & $5.10 \pm 0.54 b$ & $5.46 \pm 0.33 b$ \\
\hline 100 & $1.17 \pm 0.05 \mathrm{ab}$ & $0.451 \pm 0.023 c$ & $5.27 \pm 0.21 b$ & $2.73 \pm 0.28 \mathrm{a}$ & $0.68 \pm 0.03 b c$ & $4.50 \pm 0.41 b$ & $1.32 \pm 0.48 \mathrm{c}$ \\
\hline 200 & $1.19 \pm 0.06 \mathrm{ab}$ & $0.523 \pm 0.005 b$ & $6.19 \pm 0.18 a$ & $2.86 \pm 0.19 a$ & $0.60 \pm 0.06 c$ & $4.54 \pm 0.42 b$ & $1.49 \pm 0.14 \mathrm{c}$ \\
\hline 500 & $1.09 \pm 0.01 b$ & $0.570 \pm 0.011 \mathrm{a}$ & $6.56 \pm 0.16 \mathrm{a}$ & $2.86 \pm 0.07 \mathrm{a}$ & $0.46 \pm 0.01 \mathrm{~d}$ & $4.58 \pm 0.41 \mathrm{~b}$ & $1.83 \pm 0.48 \mathrm{C}$ \\
\hline
\end{tabular}

Data represent means \pm SE of replications. Similar lower letters indicate that there is no significant difference at $P<0.05$.

significantly decreased in the treated plants compared to the control group (Table 2). After exposure to 500 mg L ${ }^{-1}$ concentration of $\mathrm{ZnO}-\mathrm{NPs}$, the activity of CAT, POX, and APX was reduced 2.23-, 1.60-, and 3.91-fold, respectively, compared with the control group.

\section{Discussion}

In this study, guar gum was used for the first time in the co-precipitation process for the synthesis of $\mathrm{ZnO}$ NPs. The plant materials such as gums, can be used as reducing, stabilizing and biocompatible agents which makes them suitable for the synthesis of nanoparticles. Thus, in the current work the guar gum was used for the green synthesis of $\mathrm{ZnO}-\mathrm{NPs} .{ }^{27}$ Various studies have used nanoparticles of different sizes as fertilizers or pesticides. In foliar spraying, the size of nanoparticles is inversely related to their penetration. ${ }^{28}$ Nanoparticles with a size of 200 to $300 \mathrm{~nm},{ }^{29}$ even up to an average of $500 \mathrm{~nm}$ have been shown to penetrate the leaves of various plants. ${ }^{30}$ Therefore, we used nanoparticles with a size of $40 \mathrm{~nm}$ to ensure their successful penetration into leaves.

Because leaves are the main organs for photosynthesis and carbohydrate production, the main part of examinations were focused on their features. The seeds were also assayed as an important part of plant in gum production.

It is the first study of its kind to report on the effects of $\mathrm{ZnO}$-NPs on the landrace Saravan. According to the obtained results, $\mathrm{ZnO}$-NPs have a positive influence on the $\mathrm{Zn}$ concentration of the leaf and also on the yield of the guar plant. This observation reveals the possible absorption of zinc by the tissue of the guar leaves. Similar results have been reported in some previous studies. For example, in Vigna radiata, application of zinc in the root environment increased the zinc content of the plant. ${ }^{31}$

Exposure to $\mathrm{ZnO}-\mathrm{NPs}$ resulted in an increase in photosynthetic pigment contents. In a previous study on wheat, ZnO-NPs and Fe-NPs significantly increased photosynthetic pigment content (chlorophyll a, chlorophyll b, carotenoids), and biomass. ${ }^{32}$ Zinc increases chlorophyll content because it not only acts as a structural component, but also participates in the chemical catalysis of enzymes. In addition, zinc is a cofactor for the progress of pigment biosynthesis. ${ }^{31}$ Overall, exposure of guar to $\mathrm{ZnO}-\mathrm{NPs}$ has a positive effect on photosynthetic pigment content.

The content of soluble sugar in guar leaves decreased with increasing $\mathrm{ZnO}-\mathrm{NPs}$ concentration and reached its highest value at the maximum $\mathrm{ZnO}-\mathrm{NPs}$ concentration $(500 \mathrm{mg} / \mathrm{L})$, while the content of insoluble sugar tended to enhance with increasing $\mathrm{ZnO}-\mathrm{NPs}$ concentration. In fair agreement with our results, exposure of winter wheat to supporting nanomaterials boosted grain yield and protein content and reduced the amount of soluble sugar. ${ }^{33}$ Similarly, in willow plant, treatment with $\mathrm{Zn}$ significantly increased the amount of carbohydrates. ${ }^{34}$ It is known that several $\mathrm{Zn}$-dependent enzymes in leaves are responsible for the metabolism of carbohydrate. ${ }^{35} \mathrm{Zn}$ is also necessary for several photosynthetic reactions. ${ }^{36}$ One of the functions of $\mathrm{Zn}$ in promoting sugars may be related to its role in maintaining cell membrane stability, which is due to NADPH-dependent oxygen production. ${ }^{37}$ In our study, increasing the concentration of $\mathrm{ZnO}-\mathrm{NPs}$ elevated the amount of insoluble carbohydrates in the leaves. The 
simultaneous decrease in the amounts of soluble sugars confirmed their consumption in metabolic pathways to produce different classes of polysaccharides (insoluble sugars).

The content of guar gum improved with the increase of the $\mathrm{ZnO}-\mathrm{NPs}$ concentration. There are few studies on the effects of zinc on the gums of various plants. In a previous study on the guar plant, increasing $\mathrm{Zn}$ in soil from 0 to $10 \mathrm{~kg} \mathrm{ha}^{-1}$ increased gum content from $25.52 \%$ to $31.37 \%{ }^{38}$ In another similar study, application of $\mathrm{ZnO}-\mathrm{NPs}$ at a concentration of $10 \mathrm{mg} \mathrm{L}^{-1}$ to guar leaf resulted in a $7.5 \%$ increase in gum content. ${ }^{39} \mathrm{Zinc}$ affects the polysaccharide content of seeds by improving photosynthetic metabolism, which increases the ability of seeds to produce sugars. In addition, zinc can increase nutrient uptake by elongating the roots, which directly increases the accumulation of seed carbohydrates.

The level of soluble proteins increased after ZnO-NPs treatments. Zinc is not only involved in the regulation of gene expression, but is also a cofactor for RNA polymerase and protein synthesis. Thus, it is conceivable that its concentration affects protein biosynthesis. Alternatively, the reason for the protein increase may be related to the role of zinc in gene expression, activity of enzymes and factors required for protein synthesis. A similar pattern was observed in previous studies. In Cicer arietinum, a significant increase in protein content was indicated after exposure to $100 \mathrm{mg} \mathrm{L}-1 \mathrm{ZnO}-\mathrm{NPs} .{ }^{39}$ Consistent with these findings, the amount of protein synthesis in bean was drastically reduced under zinc deficiency. Furthermore, structural damage to ribosomes and RNA molecules was observed under zinc deficiency, confirming the crucial effect of zinc on protein biosynthesis. ${ }^{40}$

The activity of the antioxidant enzymes, significantly reduced in the treated plants. The results were consistent with previous findings showing a reduction in the activity of antioxidant enzymes after zinc treatment, possibly due to reducing stress conditions. ${ }^{40}$ Similarly, the activity of antioxidant enzymes in tangerine was decreased at the optimal concentration of zinc. ${ }^{41}$ It should be noted that plants use antioxidant enzymes to overcome the damage caused by reactive oxygen species (ROS). Therefore, one may conclude that the concentrations of $\mathrm{ZnO}-\mathrm{NPs}$ used did not induce ROS production in the treated plants. In this study, the effects of $\mathrm{ZnO}-\mathrm{NPs}$ up to $500 \mathrm{mg} \mathrm{L}^{-1}$ were investigated. The physiological behavior of guar at the higher concentrations is unclear. Assessing the higher concentrations and study of their physiological impacts may be regarded as the goals of further researches.

\section{Conclusion}

In this study, ZnO-NPs with an average size of $40 \mathrm{~nm}$ were green-synthesized using guar gum. Determination of their characteristics using UV-Vis, SEM, TEM, EDX, FTIR, and XRD showed that they are suitable candidates for physiological applications. Subsequently, the effects of the synthesized $\mathrm{ZnO}$-NPs on Saravan landrace of guar were studied. The $\mathrm{ZnO}-\mathrm{NPs}$ were sprayed on the leaves of guar at concentrations of $0,25,50,100,200$ and $500 \mathrm{mg}$ $\mathrm{L}^{-1}$. Application of $\mathrm{ZnO}-\mathrm{NPs}$ increased $\mathrm{Zn}$ concentration and the content of photosynthetic pigments of guar plant in a concentration dependent pattern. Accordingly, after exposure to $500 \mathrm{mg} \mathrm{L}^{-1}$ of $\mathrm{ZnO}-\mathrm{NPs}$, the gum production was increased by $55.08 \%$. Concurrently, the amounts of soluble proteins and insoluble sugars increased and the amount of soluble sugars dropped. The activity of antioxidant enzymes gradually decreased showing that the applied concentrations of $\mathrm{ZnO}-\mathrm{NPs}$ did not induce a significant oxidative stress. The results suggest that $\mathrm{ZnO}-\mathrm{NPs}$ synthesized with the bio-friendly procedure are suitable candidates for improving physiological properties, and guar gum for use in pharmaceutical, and therapeutic approaches.

\section{Ethical Approval}

Not applicable, because this article does not contain any studies with human or animal subjects.

\section{Competing Interest}

The authors declare that there are no competing interests.

\section{Funding/Support}

Not applicable.

\section{Authors' Contributions}

SB: Conduction of the experiments, data analysis, preparing the original draft of manuscript. JV: Conceptualization. MV: Consultation. AM: Research supervision, preparing the manuscript.

\section{Acknowledgements}

This work was financially supported by the University of Tabriz. The authors acknowledge the Biology Department of Sistan and Baluchestan University for providing the greenhouse as well as experimental facilities and the Payame Noor University of Zahedan, Iran for preparing some of the research materials.

\section{References}

1. Gresta F, Mercati F, Santonoceto C, et al. Morpho-agronomic and AFLP characterization to explore guar (Cyamopsis tetragonoloba L.) genotypes for the Mediterranean environment. Ind Crops Prod. 2016;86:23-30. doi:10.1016/j. indcrop.2016.03.038

2. Mudgil D, Barak S, Khatkar BS. Guar gum: processing, properties and food applications-a review. J Food Sci Technol. 2014;51(3):409-418. doi:10.1007/s13197-011-0522-x

3. Gupta AP, Verma DK. Guar gum and their derivatives: a research profile. Int J Adv Res. 2014;2(1):680-690.

4. Archer DL, Kramer DC. The use of microbial accessible and fermentable carbohydrates and/or butyrate as supportive treatment for patients with coronavirus SARS-CoV-2 infection. Front Med (Lausanne). 2020;7:292. doi:10.3389/ fmed.2020.00292

5. Al-Qurainy F, Alshameri A, Gaafar AR, et al. Comprehensive stress-based de novo transcriptome assembly and annotation of guar (Cyamopsis tetragonoloba (L.) Taub.): 
an important industrial and forage crop. Int J Genomics. 2019;2019:7295859. doi:10.1155/2019/7295859

6. Rana V, Rai P, Tiwary AK, Singh RS, Kennedy JF, Knill CJ. Modified gums: approaches and applications in drug delivery. Carbohydr Polym. 2011;83(3):1031-1047. doi:10.1016/j. carbpol.2010.09.010

7. KoleC, Kumar DS, Khodakovskaya MV. Plant Nanotechnology: Principles and Practices. Springer International Publishing; 2016.

8. Salem W, Leitner DR, Zingl FG, et al. Antibacterial activity of silver and zinc nanoparticles against Vibrio cholerae and enterotoxic Escherichia coli. Int J Med Microbiol. 2015;305(1):85-95. doi:10.1016/j.ijmm.2014.11.005

9. Maret W. Zinc in cellular regulation: the nature and significance of "zinc signals". Int J Mol Sci. 2017;18(11):2285. doi:10.3390/ijms 18112285

10. Maret W. Zinc biochemistry: from a single zinc enzyme to a key element of life. Adv Nutr. 2013;4(1):82-91. doi:10.3945/ an.112.003038

11. Rico CM, Majumdar S, Duarte-Gardea M, Peralta-Videa JR, Gardea-Torresdey JL. Interaction of nanoparticles with edible plants and their possible implications in the food chain. J Agric Food Chem. 2011;59(8):3485-3498. doi:10.1021/jf104517j

12. Zhang $T$, Sun $H$, Lv Z, Cui L, Mao H, Kopittke PM. Using synchrotron-based approaches to examine the foliar application of $\mathrm{ZnSO} 4$ and $\mathrm{ZnO}$ nanoparticles for field-grown winter wheat. J Agric Food Chem. 2018;66(11):2572-2579. doi:10.1021/acs.jafc.7b04153

13. Fageria NK, Filho MPB, Moreira A, Guimarães CM. Foliar fertilization of crop plants. J Plant Nutr. 2009;32(6):10441064. doi:10.1080/01904160902872826

14. Zhao L, Peralta-Videa JR, Ren M, et al. Transport of $Z n$ in a sandy loam soil treated with $\mathrm{ZnO} N P s$ and uptake by corn plants: electron microprobe and confocal microscopy studies. Chem Eng J. 2012;184:1-8. doi:10.1016/j.cej.2012.01.041

15. Meftahizadeh $\mathrm{H}$, Ghorbanpour $\mathrm{M}$, Asareh $\mathrm{MH}$. Changes in phenological attributes, yield and phytochemical compositions of guar (Cyamopsis tetragonoloba L.) landaraces under various irrigation regimes and planting dates. Sci Hortic. 2019;256:108577. doi:10.1016/j.scienta.2019.108577

16. Darroudi M, Sabouri Z, Kazemi Oskuee R, Khorsand Zak A, Kargar H, Abd Hamid MH. Sol-gel synthesis, characterization, and neurotoxicity effect of zinc oxide nanoparticles using gum tragacanth. Ceram Int. 2013;39(8):9195-9199. doi:10.1016/j. ceramint.2013.05.021

17. Niesiobedzka K. Mobile forms and migration ability of $\mathrm{Cu}$, $\mathrm{Pb}$ and $\mathrm{Zn}$ in forestry system in Poland. Environ Earth Sci. 2016;75(2):122. doi:10.1007/s12665-015-4821-9

18. Lichtenthaler HK. Chlorophylls and carotenoids: pigments of photosynthetic biomembranes. Methods Enzymol. 1987;148(C):350-382. doi:10.1016/0076-6879(87)48036-1

19. Nielsen SS. Phenol-sulfuric acid method for total carbohydrates. In: Nielsen SS, ed. Food Analysis Laboratory Manual. Boston, MA: Springer; 2010:47-53. doi:10.1007/9781-4419-1463-7_6

20. Hellebust JA, Craigie JS. Handbook of Phycological Methods: Physiological and Biochemical Methods. Cambridge University Press; 1978:512

21. Bradford MM. A rapid and sensitive method for the quantitation of microgram quantities of protein utilizing the principle of protein-dye binding. Anal Biochem. 1976;72:248-254. doi:10.1006/abio.1976.9999

22. Chance B, Maehly AC. Assay of catalases and peroxidases.
Methods Enzymol. 1955;2(1929):764-775. doi:10.1016/ s0076-6879(55)02300-8

23. Boominathan $\mathrm{R}$, Doran PM. Ni-induced oxidative stress in roots of the $\mathrm{Ni}$ hyperaccumulator, Alyssum bertolonii. New Phytol. 2002;156(2):205-215. doi:10.1046/j.14698137.2002.00506.x

24. Javed R, Usman M, Yücesan B, Zia M, Gürel E. Effect of zinc oxide $(\mathrm{ZnO})$ nanoparticles on physiology and steviol glycosides production in micropropagated shoots of Stevia rebaudiana Bertoni. Plant Physiol Biochem. 2017;110:94-99. doi:10.1016/j.plaphy.2016.05.032

25. Pal S, Mondal S, Maity J, Mukherjee R. Synthesis and characterization of $\mathrm{ZnO}$ nanoparticles using Moringa oleifera leaf extract: investigation of photocatalytic and antibacterial activity. Int J Nanosci Nanotechnol. 2018;14(2):111-119.

26. Ramesh M, Anbuvannan M, Viruthagiri G. Green synthesis of $\mathrm{ZnO}$ nanoparticles using Solanum nigrum leaf extract and their antibacterial activity. Spectrochim Acta A Mol Biomol Spectrosc. 2015;136 Pt B:864-870. doi:10.1016/j. saa.2014.09.105

27. Amiri MS, Mohammadzadeh V, Taghavizadeh Yazdi ME, Barani M, Rahdar A, Kyzas GZ. Plant-based gums and mucilages applications in pharmacology and nanomedicine: a review. Molecules. 2021;26(6):1770. doi:10.3390/ molecules26061770

28. Tarafdar JC, Xiong Y, Wang WN, Quinl D, Biswas P. Standardization of size, shape and concentration of nanoparticle for plant application. Appl Biol Res. 2012;14(2):138-144.

29. Xu Y, Xu C, Huang Q, Cao L, Teng F, Zhao P, Jia M. Size effect of mesoporous silica nanoparticles on pesticide loading, release, and delivery in cucumber plants. Appl Sci. 2021;11(2):575. doi:10.3390/app11020575

30. Ha NMC, Nguyen TH, Wang SL, Nguyen AD. Preparation of NPK nanofertilizer based on chitosan nanoparticles and its effect on biophysical characteristics and growth of coffee in green house. Res Chem Intermed. 2019;45(1):51-63. doi:10.1007/s11164-018-3630-7

31. Samreen T, Humaira, Shah HU, Ullah S, Javid M. Zinc effect on growth rate, chlorophyll, protein and mineral contents of hydroponically grown mungbeans plant (Vigna radiata). Arab J Chem. 2017;10 Suppl 2:S1802-S1807. doi:10.1016/j. arabjc.2013.07.005

32. Rizwan M, Ali S, Ali B, et al. Zinc and iron oxide nanoparticles improved the plant growth and reduced the oxidative stress and cadmium concentration in wheat. Chemosphere. 2019;214:269-277. doi:10.1016/j.chemosphere.2018.09.120

33. Xiao Q, Zhang FD, Wang YY, Zhang JF, Zhang SQ. Effects of slow/controlled release fertilizers felted and coated by nanomaterials on crop yield and quality. Plant Nutr Fertil Sci. 2008;14(5):951-955.

34. Borowiak K, Gąsecka M, Mleczek M, et al. Photosynthetic activity in relation to chlorophylls, carbohydrates, phenolics and growth of a hybrid Salix purpurea $\times$ triandra $\times$ viminalis 2 at various $\mathrm{Zn}$ concentrations. Acta Physiol Plant. 2015;37(8):155. doi:10.1007/s11738-015-1904-x

35. Xing F, Fu XZ, Wang NQ, et al. Physiological changes and expression characteristics of ZIP family genes under zinc deficiency in navel orange (Citrus sinensis). J Integr Agric. 2016;15(4):803-811. doi:10.1016/s2095-3119(15)61276-x

36. Blasco B, Navarro-León E, Ruiz JM. Study of Zn accumulation and tolerance of HMA4 TILLING mutants of Brassica rapa grown under $\mathrm{Zn}$ deficiency and $\mathrm{Zn}$ toxicity. Plant Sci. 
2019;287:110201. doi:10.1016/j.plantsci.2019.110201

37. Noman A, Ali Q, Maqsood J, et al. Deciphering physiobiochemical, yield, and nutritional quality attributes of water-stressed radish (Raphanus sativus L.) plants grown from Zn-Lys primed seeds. Chemosphere. 2018;195:175-189. doi:10.1016/j.chemosphere.2017.12.059

38. Meena KR, Dahama AK, Reager ML. Effect of phosphorus and zinc fertilization on growth and quality of clusterbean [Cyamopsis tetragonoloba (L.) Taub.]. Ann Agric Res. 2006;27(3):224-226

39. Raliya R, Tarafdar JC. ZnO nanoparticle biosynthesis and its effect on phosphorous-mobilizing enzyme secretion and gum contents in clusterbean (Cyamopsis tetragonoloba L.). Agric Res. 2013;2(1):48-57. doi:10.1007/s40003-012-0049-z

40. Kučerová K, Henselová M, Slováková L, Hensel K. Effects of plasma activated water on wheat: germination, growth parameters, photosynthetic pigments, soluble protein content, and antioxidant enzymes activity. Plasma Process Polym. 2019;16(3):1800131. doi:10.1002/ppap.201800131

41. Subba P, Mukhopadhyay M, Mahato SK, Bhutia KD, Mondal TK, Ghosh SK. Zinc stress induces physiological, ultrastructural and biochemical changes in mandarin orange (Citrus reticulata Blanco) seedlings. Physiol Mol Biol Plants. 2014;20(4):461-473. doi:10.1007/s12298-014-0254-2 